\title{
Dietary Overlap between Sheep, Cattle, and Goats when Grazing in Common
}

\author{
V.R. SQUIRES
}

\section{Abstract}

The chemical and butanical composition of the diets of esophageally fistulated sheep, cattle, and goats was monitored over a period of 1 year at intervals of approximately 2 months. The animals were grazing together in a poplar box (Eucalyptus populnea) woodland community with an understory of shrubs, chiefly Cassia and Eremophila spp., and an herbaceous field layer of grasses and forbs. Diet quality, as assessed by in vitro digestibility, was highest for sheep in all seasons. The degree of dietary overlap, and hence potential competition, was greatest between goats and cattle. Both goats and cattle had a high proportion of browse plants in their diets. Discussion centres on the degree of overlap in the diets and the complementarity of grazing under common-use.

Semiarid rangelands in Australia produce forage which can be utilized by more than one kind of animal-usually cattle or sheep. Common-use grazing, the concurrent use of the rangeland by more than one kind of animal, has been advocated as a means of maximising animal production (Merrill and Miller 1961). As a prerequisite to studies on animal and rangeland productivity under common-use grazing, it seemed desirable to evaluate the degree of potential competition between livestock species as indicated by the extent to which they select the same plant species.

Dietary preferences of livestock are commonly assessed by means of esophageally fistulated animals (Van Dyne and Torell 1964). Several studies in western New South Wales involving comparison of diets selected by livestock when grazing together have been reported. Wilson et al. (1975) studied diets of sheep and goats in a rosewood-belah (Heterodendrum-Casuarina) woodland, and Wilson (1976) compared the diets of sheep and cattle in a semiarid grassland. Squires (1980) compared the diets of sheep, cattle, and goats grazing in a poplar box (Eucalyptus populnea) woodland. Attempts to assess the degree of dietary overlap by livestock species are less commonly reported. The study by Hansen and Reid (1975) is typical of many in North America in which the interaction between wildlife and range livestock was assessed.

The present paper summarises information gathered over a 1-year period from a study involving sheep, cattle, and goat diets under common-use grazing in a semiarid woodland. Both chemical and botanical composition of the diets were evaluated. Degree of dietary overlap was assessed. Full details of the methods employed and the results of comparisons of diets selected by the three livestock species are in Squires (1980).

\section{Methods}

The study was conducted during 1974-75 at the CSIRO Coolabah study site in northwest New South Wales. The study area, located in a semiarid poplar box woodland, had a dense understory of shrubs, principally turpentine (Eremophila), hopbush (Dodonea), and cassia (Cassia) spp. The field layer was dominated by grasses, chiefly speargrass (Stipa), greybeard grass (Amphipogon),

\footnotetext{
Author is Dean of the Faculty of Natural Resources, Department of Natural Resources, Ruseworthy Agricultural College, Roseworthy, South Australia, 5371. The author would like to thank Mr. W. Müller, CSIRO Division of Mathematics and Statistics, Canberra, for the statistical analysis, and Mr. P. Mills for able technical assistance. An a bstract of this paper was originally published in the Proceedings of the III World Congress on Animal Feeding, Madrid 1978

Manuscript received April 8, 1980.
}

and three awns, (Aristida) spp., and forbs (chiefly Composites and Chenopods). The availability and botanical composition of the field layer species were obtained by hand clipping 80 quadrats $\left(\mathrm{lm}^{2}\right)$ on six occasions, at bimonthly intervals. The contribution of shrubs and trees to the amount of forage on offer was not assessed quantitatively. The height and frequency of occurrence of tree and shrub species along $80 \mathrm{~m}$ of belt transect were recorded.

Esophageal fistulas were installed in six sheep (Merino wethers), six cattle (Angus yearlings), and six goats (of feral origin). A minimum of four animals of each species were used in the diet study. Collections of extrusa were made every 2 months by introducing the fistulated animals into a 20 -ha paddock of known botanical composition. During the period when collections were not being made, the animals were grazed together on an adjacent area of similar botanical composition.

Dietary samples were collected over a 45-50 minute period after an overnight fast. Collections were made from each animal species group in turn on successive days. Extrusa from each of the individuals/comprising an animal group were collected and analysed separately. Samples obtained were analysed for botanical composition by hand sorting the fresh extrusa into the component species. For convenience in considering the results, four major plant groupings were used: shrubs, grasses, forbs, and dead material. The sub sample for determination of nitrogen and phosphorus content and in vitro digestibility were frozen, freeze dried, and ground in a Wiley mill. Nitrogen was determined by an automated Kjeldahl method. In vitro digestibility was determined by the method of Minson and McLeod (1972), using correction according to a standard herbaceous forage for which the in vivo digestibility was known. A preference index as proposed by Taylor (1973) was calculated as follows:

$$
\mathbf{P I}=\frac{\% \text { in diet }-\% \text { available }}{\% \text { in diet }+\% \text { available }} \times 10
$$

where $\%$ in diet and $\%$ available refer to the proportion of a given forage species in the diet and the pasture on offer, respectively. The index has scale from -10 to +10 indicating relative preference. A value about zero would indicate selection in proportion to availability.

Degree of diet overlap was assessed by means of the simple index proposed by Dunbar (1978) in which the percentage points from each dietetic class which are common to both animal species are summed. Values are expressed as a coefficient in the range of 0-100.

\section{Results}

\section{Botanical Composition}

There were 96 species on offer in the study area but diets contained a maximum of 18 species. Of these, only 12 were sufficiently conspicuous to warrant attention. For ease of presentation the diets will be considered in the four categories referred to above. Goats ate more shrubs than either sheep or cattle at all samplings but the differences failed to reach significance on some occasions (Table 1). Sheep maintained a high proportion of green grass in 
Table 1. Trends in diet selected by sheep, cattle, and goats in a semiarid woodland community in northwest New South Wales.'

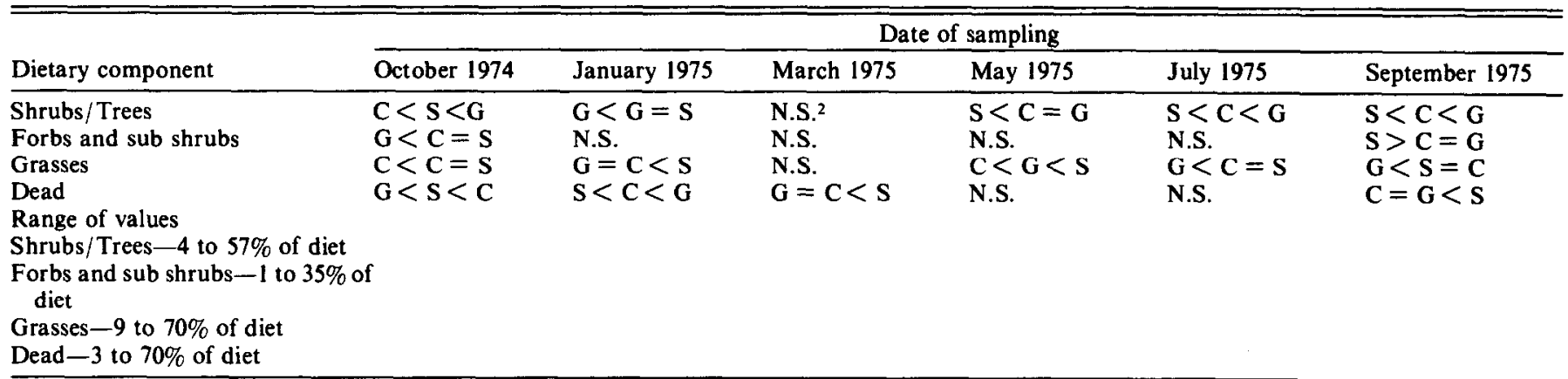

'Derived from ANOV with 71 d.f.

${ }^{2}$ N.S. = not statistically significant at $5 \%$ level of probability.

their diets in all occasions despite a low level of availability. Cattle did not harvest the generally sparse and short purple lovegrass (Eragrostis lacunaria), which was the major component of the diet of sheep. Instead cattle selected senescent variable spear grass (Stipa variabilis) when other forages were in short supply. Forbs were a minor part of the diet in all but spring because of low availability.

Burr daisies (Calotis spp.) and the chenopods, grey copper burr (Bassia diacantha) and goosefoot (Chenopodium anidiophyllum), were the principal forbs in spring and contributed $30 \%$ to the diet of both sheep and cattle. Seasonal variation in green forage on offer is shown in Table 2.

\section{Chemical Composition}

Sheep maintained a higher quality diet than either cattle or goats. In vitro digestibility values averaged 5-6 percentage points higher than cattle or goat diets. Digestibility was low $(<50 \%)$ in most seasons reflecting the high intake of shrubs of low digestibility (Wilson 1977). Percentage nitrogen in the diet was highest in shcep $(1.26 \%)$ lowest in cattle $(1.17 \%)$ and intermediate in goats $(1.20 \%)$. Seasonal variations in the nitrogen and phosphorus content of the forage on offer and the in vitro digestibility of the diets selected are shown in Figure 1.

\section{Preference Index}

Sheep were the most highly selective. Their preference for green grass was shown by the PI values of +8 and higher which were associated with purple lovegrass (Table 3). Cattle showed a high preference for copper burr and for goosefoot $(+7$ and +6 respeclively). Goats preferred to browse mulga (Acacia aneura) and, on occasions, graze burr daisies $(+6)$. The generally rare mulga grass (Thyridolepis mitchelli) and bandicoot grass (Monochather paradoxa) were highly preferred and had PI values in excess of +9 but were rarely contributing more than $2 \%$ to the diet.

Table 2. Seasonal variation in green forage dry matter on offer in the field layer. ${ }^{1}$

\begin{tabular}{|c|c|c|c|c|c|c|c|}
\hline \multirow[b]{2}{*}{$\begin{array}{l}\text { Date of } \\
\text { harvest }\end{array}$} & \multicolumn{7}{|c|}{ Weight and percentage of each component } \\
\hline & $\begin{array}{l}\text { Grass } \\
\mathrm{kg} / \mathrm{ha}\end{array}$ & $\%$ & $\begin{array}{l}\text { Forbs } \\
\text { kg/ha }\end{array}$ & $\%$ & $\begin{array}{c}\text { Sub } \\
\text { Shrubs } 2 \\
\text { kg/ha }\end{array}$ & $\%$ & $\begin{array}{l}\text { Total } \\
\mathrm{kg} / \mathrm{ha}\end{array}$ \\
\hline Oct. 1974 & 1372 & 73.0 & 359 & 9.6 & 653 & 17.3 & 2384 \\
\hline Jan. 1975 & 695 & 63.4 & 11.5 & 8.0 & 550 & 27.6 & 1390 \\
\hline Mar. 1975 & 611 & 95.9 & 3 & 0.4 & 23 & 3.7 & 637 \\
\hline May 1975 & 694 & 95.3 & 4 & 0.6 & 30 & 4.1 & 728 \\
\hline July 1975 & 520 & 96.6 & 1 & 0.1 & 18 & 3.2 & 538 \\
\hline Sept. 1975 & 195 & 90.0 & 0 & 0.0 & 7 & 4.0 & 219 \\
\hline
\end{tabular}

The edible shrubs and trees were not assessed quantitatively. These data refer only to forage clipped from the ground.

${ }^{2}$ Principally, woody Malvaceae and Chenopodiaceae.

\section{Diet Overlap}

The degree of diet overlap varied seasonally (Table 4). The overlap was greatest between sheep and cattle and least between sheep and goats. Degree of overlap was lowest during the summer (January) when the proportion of shrubs and browse in the diets showed the greatest divergence (Table 1) and hi hest in autumn when all three livestock species ate considerable amounts of grass.

The utility of the index of diet overlap is obviously sensitive to the fineness of the division of forage classes. The greatest apparent overlap occurred when the forages were grouped into broad cate-
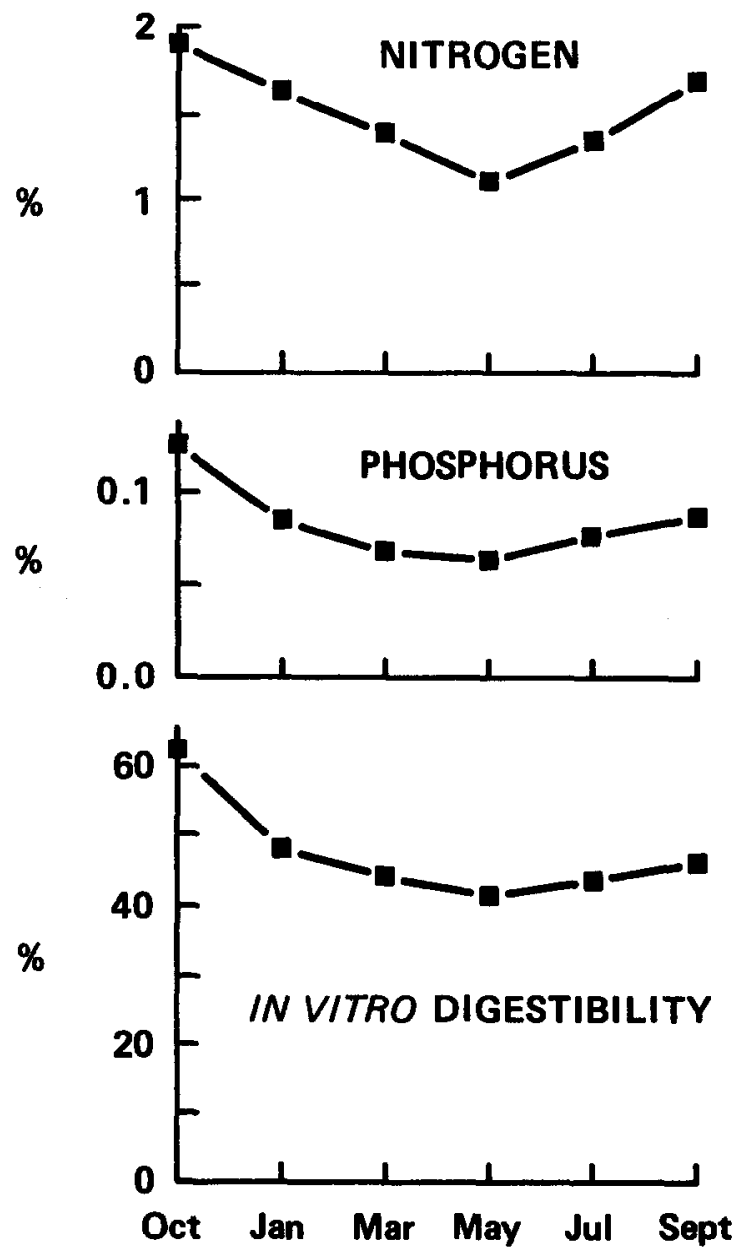

Fig. 1. Seasonal variations in quality of forage on offer and in digestibility of the diet selected. In vitro digestibility values shown represent the mean value for all animals (sheep, cattle, and goats). 
Table 3. Relative preference values 1 for major species in the diets of sheep, cattle, and góats in six collection periods from October 1974 to September 1975.

\begin{tabular}{|c|c|c|c|c|c|c|c|c|c|c|c|c|c|c|c|c|c|c|}
\hline \multirow[b]{3}{*}{ Species } & \multicolumn{18}{|c|}{ Dates } \\
\hline & \multicolumn{3}{|c|}{ Oct. 1974} & \multicolumn{3}{|c|}{ Jan. 1975} & \multicolumn{3}{|c|}{ Mar. 1975} & \multicolumn{3}{|c|}{ May 1975} & \multicolumn{3}{|c|}{ July 1975} & \multicolumn{3}{|c|}{ Sept. 1975} \\
\hline & $\mathbf{S}$ & C & $\mathbf{G}$ & $\mathbf{S}$ & $\mathrm{C}$ & $\mathbf{G}$ & $\mathbf{S}$ & $\mathrm{C}$ & $\mathrm{G}$ & $\mathbf{S}$ & $\mathrm{C}$ & $\mathbf{G}$ & $\mathbf{S}$ & $\mathrm{C}$ & $\mathrm{G}$ & $\mathrm{S}$ & $\mathrm{C}$ & $\mathbf{G}$ \\
\hline $\begin{array}{l}\text { Shrubs and trees } 2 \\
\text { Acacia aneura } \\
\text { Dodonea viscosa } \\
\text { Apophyllum anomalum }\end{array}$ & $\begin{array}{l}++3 \\
-4 \\
-\end{array}$ & $\begin{array}{l}++ \\
- \\
-\end{array}$ & $\begin{array}{l}++ \\
- \\
-\end{array}$ & $\begin{array}{l}++ \\
- \\
-\end{array}$ & $\begin{array}{l}++ \\
- \\
-\end{array}$ & $\begin{array}{l}++ \\
- \\
-\end{array}$ & $\begin{array}{l}++ \\
- \\
-\end{array}$ & $\begin{array}{l}++ \\
- \\
-\end{array}$ & $\begin{array}{l}++ \\
- \\
-\end{array}$ & $\begin{array}{l}++ \\
- \\
+\end{array}$ & $\begin{array}{l}++ \\
+ \\
+\end{array}$ & $\begin{array}{l}++ \\
+ \\
+\end{array}$ & $\begin{array}{l}++ \\
- \\
+\end{array}$ & $\begin{array}{c}++ \\
+++ \\
++\end{array}$ & $\begin{array}{l}++ \\
++ \\
++\end{array}$ & $\begin{array}{l}++ \\
- \\
-\end{array}$ & $\begin{array}{l}++ \\
- \\
-\end{array}$ & $\begin{array}{l}++ \\
- \\
+\end{array}$ \\
\hline $\begin{array}{l}\text { Forbs and sub sub shrubs } \\
\text { Bassia diacantha } \\
\text { Chenopodium anidiophyllum } \\
\text { Calotis spp. }\end{array}$ & $\begin{array}{l}+3 \\
+2 \\
+7\end{array}$ & $\begin{array}{l}+7 \\
+6 \\
+6\end{array}$ & $\begin{array}{l}-1 \\
+4 \\
+6\end{array}$ & $\begin{array}{l}+4 \\
+4 \\
+6\end{array}$ & $\begin{array}{l}+8 \\
+7 \\
+6\end{array}$ & $\begin{array}{l}+1 \\
+4 \\
+2\end{array}$ & $\begin{array}{l}+2 \\
+4 \\
+5\end{array}$ & $\begin{array}{l}+8 \\
+7 \\
+3\end{array}$ & $\begin{array}{l}+1 \\
+4 \\
+2\end{array}$ & $\begin{array}{l}+1 \\
+6 \\
+6\end{array}$ & $\begin{array}{l}+7 \\
+8 \\
+3\end{array}$ & $\begin{array}{l}+2 \\
+3 \\
+1\end{array}$ & $\begin{array}{l}+2 \\
+2 \\
+5\end{array}$ & $\begin{array}{l}+8 \\
+6 \\
+4\end{array}$ & $\begin{array}{l}+3 \\
+1 \\
+1\end{array}$ & $\begin{array}{l}+2 \\
+2 \\
+7\end{array}$ & $\begin{array}{l}+6 \\
+5 \\
+5\end{array}$ & $\begin{array}{l}+2 \\
+1 \\
+1\end{array}$ \\
\hline $\begin{array}{l}\text { Grasses } \\
\text { Stipa variabilis (green) } \\
\text { Stipa variabilis (dry) } \\
\text { Eragrostis lacumaria } \\
\text { Panicum effusum } \\
\text { Amphipogon caricinus } \\
\text { Aristida jerichoensis }\end{array}$ & $\begin{array}{l}+8 \\
-4 \\
+8 \\
+8 \\
+2 \\
+2\end{array}$ & $\begin{array}{l}+6 \\
+3 \\
+3 \\
+7 \\
+5 \\
+4\end{array}$ & $\begin{array}{l}+5 \\
-2 \\
+7 \\
+6 \\
+3 \\
+1\end{array}$ & $\begin{array}{l}+7 \\
-4 \\
+8 \\
+8 \\
+7 \\
+4\end{array}$ & $\begin{array}{l}+2 \\
+7 \\
+2 \\
+6 \\
+7 \\
+5\end{array}$ & $\begin{array}{l}+4 \\
-3 \\
+6 \\
+6 \\
+6 \\
+3\end{array}$ & $\begin{array}{l}+7 \\
+2 \\
+7 \\
+6 \\
+4\end{array}$ & $\begin{array}{l}+4 \\
+7 \\
+2 \\
+7 \\
+5\end{array}$ & $\begin{array}{l}+5 \\
+4 \\
+6 \\
+5 \\
+4\end{array}$ & $\begin{array}{l}+6 \\
+2 \\
+8 \\
+7 \\
+6\end{array}$ & $\begin{array}{l}+4 \\
+6 \\
+3 \\
+7 \\
+6\end{array}$ & $\begin{array}{l}+2 \\
+3 \\
+7 \\
+6 \\
+4\end{array}$ & $\begin{array}{l}+7 \\
+3 \\
+8 \\
+7 \\
+5\end{array}$ & $\begin{array}{l}+4 \\
+7 \\
+3 \\
+6 \\
+6\end{array}$ & $\begin{array}{l}+2 \\
+2 \\
+6 \\
+6 \\
+7\end{array}$ & $\begin{array}{l}+7 \\
-3 \\
+9 \\
+8 \\
+3 \\
+2\end{array}$ & $\begin{array}{l}+6 \\
+2 \\
+3 \\
+7 \\
+5 \\
+4\end{array}$ & $\begin{array}{l}+5 \\
-4 \\
+7 \\
+7 \\
+4 \\
+3\end{array}$ \\
\hline
\end{tabular}

'Main body of table refers to the preference index values (see text). Values can range from -10 to +10

A value of 0 represents selection in proportion to availability.

${ }^{2}$ With shrubs there was no accurate measure of forage on offer but the amount on offer was reasonably constant.

3+means that the shrub species was preferred on a particular sampling occasions.

4-means that the shrub was avoided.

gories 'grass', 'forbs' and 'shrubs' (Table 4). Overlap was reduced when the index was computed from data derived from individual forage species (Table 4). The maximum dietary overlap for four key forage species, three grasses. and a chenopod sub shrub, is shown in Table 5.

\section{Discussion}

The choice of similar plant species indicates a possibility of competition between animal species but it is not by itself evidence of competition. One animal species must be shown to be limiting the productivity of another before competition is established.

While it is convenient to consider the dietary components as falling into groups such as forbs, grasses, or shrubs, it can mask real differences in diet selection. The same plant species were found in the diets of all three livestock species but the proportions varied. Sheep, and to a lesser extent goats, selected a high proportion of the grasses purple lovegrass, panic, and the green regrowth of variable spear grass, switching their attention to edible browse such as mulga, hopbush, and warrior bush (Apophyllum anomalum) in the dry period. The small green shoots from grasses and forbs contributed only a small amount to the diet of cattle. These were differences between the livestock in their minimum standards for acceptability of a forage species; e.g., cattle continued to eat senescent variable speargrass well after it had ceased to be acceptable to sheep or goats. These differences in diet selection can be very

Table 4. Seasonal variation in the degree of dietary overlap 1 among sheep, cattle, and goats when grazing in common.

\begin{tabular}{|c|c|c|c|c|c|c|}
\hline \multirow[b]{2}{*}{$\begin{array}{l}\text { Time } \\
\text { of year }\end{array}$} & \multicolumn{2}{|c|}{ Sheep vs cattle } & \multicolumn{2}{|c|}{ Cattle vs goats } & \multicolumn{2}{|c|}{ Goats vs sheep } \\
\hline & $\begin{array}{c}\text { By } \\
\text { species }^{2}\end{array}$ & Pooled 3 & $\begin{array}{c}\text { By } \\
\text { species }\end{array}$ & & $\begin{array}{c}\text { By } \\
\text { species }\end{array}$ & Pooled \\
\hline Oct. 1974 & 72.3 & 88.2 & 55.5 & 60.3 & 66.1 & 66.9 \\
\hline Jan. 1975 & 54.9 & 71.4 & 40.3 & 47.7 & 52.8 & 53.8 \\
\hline Mar. 1975 & 25.8 & 92.6 & 49.2 & 91.1 & 60.4 & 94.6 \\
\hline May 1975 & 40.2 & 83.8 & 64.8 & 92.5 & 66.3 & 76.3 \\
\hline July 1975 & 39.3 & 74.4 & 58.7 & 84.3 & 43.5 & 59.4 \\
\hline Sept. 1975 & 71.8 & 89.3 & 52.9 & 71.3 & 60.6 & 66.0 \\
\hline
\end{tabular}

'Based on the sum of percentage points from each dietary component (Table 1) which are common to both species.

${ }^{2}$ Dietary overlap based on individual forage species.

'Dietary overlap based on categories of plants (grasses, forbs, shrub etc. important. As Harrington (1978) has pointed out, the animal diet is selected at the plant species level and any manipulation of the grazing animal is management (conscious or unconscious) of the vegetation at the same level. Where dietary overlap occurs, separation could develop during critical periods of the year. In periods of adequate forage the plants selected by sheep, cattle and goats might be expected to be similar but as the dry period sets in and growth ceases the separation of animal diets would become apparent. Some evidence is seen in the present study, where at the initial sampling the same plant species were present in the diets of all livestock species. After a long dry spell had set in, only three species were common to all livestock diets. Because the periods following good rains will produce adequate forage on most sites, then it is the periods between these favourable times that are critical. The perennial grasses purple lovegrass, greybeard grass, panic, and variable speargrass are the basis of the diet in dry times, and at the same time shrubs such as hopbush and warrior bush increase in the diet. Mulga was favoured by all livestock species but its contribution to the diet was limited because of low availability.

Because the diets of sheep, cattle and goats were not identical, it follows that a herd comprising two or three livestock species would spread grazing pressure more equitably between plant species than would a monospecific herd. Further discussion of this important aspect is to be found in Harrington (1978). Merrill et el. (1966) showed that grazing two or more kinds of livestock on mixed vegetation (edible shrubs, grasses, and forbs) had two main benefits. First, more and different vegetation was grazed, which equalized the grazing load. Second, each animal benefits from the grazing by the two other kinds provided the stocking rate is not too

Table 5. Maximum dietary overlap among sheep, cattle and goats when grazing four key forage species under common use.1

\begin{tabular}{lccc}
\hline \hline Forage species & $\begin{array}{c}\text { Sheep vs } \\
\text { cattle }\end{array}$ & $\begin{array}{c}\text { Cattle vs } \\
\text { goats }\end{array}$ & $\begin{array}{c}\text { Goats vs } \\
\text { sheep }\end{array}$ \\
\hline Purple lovegrass & 30.7 & 30.7 & 42.1 \\
Variable speargrass & 45.8 & 40.4 & 29.8 \\
Copperburr & 18.8 & 0.3 & 0.3 \\
Mulga & 2.3 & 11.9 & 2.3
\end{tabular}

1 Based on the sum of percentage points from each forage component eaten which was common to the diet of both livestock species. 
high. These benefits relate to the action of the larger animals breaking down cdible browse, stripping moribund or less palatable plant parts, and through area-selective grazing within a pasture. It had economic benefits too (Merrill and Miller 1961). Economic factors loom large in decision-making. Although it may be possible to manipulate the plant community by altering the livestock mix, it is common for such decisions to be made without reference to sound range management principles.

\section{Literature Cited}

Dunbar, R.I.M. 1978. Competition and niche separation in a high altitude herbivore community in Ethiopia. E. Afr. Wildl. J. 16:183-199.

Hansen, R.M., and L.D. Reid. 1975. Diet overlap of deer, elk and cattle in southern Colorado. J. Range Manage. 28:43-47.

Harrington, G.N. 1978. The implications of goat, sheep and cattle diet to the management of an Australian semiarid woodland. Proc. Ist. Internat. Rangelands Congr. Denver, Soc. Range Manage. p. 447-50.

Merrill, L.B., and J.E. Miller. 1961. Economic analysis of yearlong grazing rate studies on substation No. 14, near Sonora. Texas A\&M Univ. Bull. MP-484.
Merrill, L.B., P.O. Reardon, and C.L. Leinweber. 1968. Cattle, sheep and goats. . mix'em up for higher gains. Texas Agr. Progr. 12:13-14.

Minson, D.J., and N.M. McLeod. 1972. The in vitro technique: its modification for estimating digestibility of large numbers of tropical pasture samples. CSIRO (Aust.) Trop. Past. Tech. Pap. No. 8.

Squires, V.R. 1980. Chemical and botanical composition of the diets of esophageally fistulated sheep, cattle and goats in a semiarid Eucalyptus populnea woodland community. Aust. Rangel. J. 2:94-103.

Taylor, C.A., 1973. The botanical composition of cattle diets on a 7-pasture high-intensity low-frequency grazing system. M.S. Thesis, Texas A\&M Univ.

Van Dyne, G.M., and D.T. Torell. 1964. Development and use of the esophageal fistula: a review J. Range Manage. 17:7-19.

Wilson, A.D. 1976. Comparison of sheep and cattle grazing on a semiarid grassland. Austr. J. Agric. Res. 27:155-62.

Wilson, A.D., 1977. Digestibility and voluntary intake of the leaves of trees and shrubs by sheep and goats. Aust. J. Agric. Res. 28:501-8.

Wilson, A.D., J.H. Leigh, N.L. Hindley, and W.E. Mulham. 1975. Comparison of the diets of goats and sheep on a Casuarina cristataHeterodendrum oleifolium woodland community in western New South Wales. Aust. J. Exp. Agr. Anim. Husb. 15:45-53. 